\title{
Effect of Harvesting Methods on Storage Behaviour of Mandarin (Citrus Reticulata Blanco) Under Cellar Condition
}

\author{
Pradeep Raj Rokaya ${ }^{1}$, , Dilli Ram Baral ${ }^{1}$, Durga Mani Gautam ${ }^{1}$, Arjun Kumar Shrestha ${ }^{1}$, \\ Krishna Prasad Paudyal ${ }^{2}$ \\ ${ }^{1}$ Department of Horticulture, Faculty of Agriculture, Agriculture and Forestry University, Rampur, Chitwan, Nepal \\ ${ }^{2}$ National Agricultural Research Institute (NARI), NARC, Khumaltar, Nepal
}

\section{Email address:}

rokayapradeep@yahoo.com (P. R. Rokaya)

${ }^{*}$ Corresponding author

\section{To cite this article:}

Pradeep Raj Rokaya, Dilli Ram Baral, Durga Mani Gautam, Arjun Kumar Shrestha, Krishna Prasad Paudyal. Effect of Harvesting Methods on Storage Behaviour of Mandarin (Citrus Reticulata Blanco) Under Cellar Condition. International Journal of Science and Qualitative Analysis. Vol. 6, No. 1, 2020, pp. 8-12. doi: 10.11648/j.jisqa.20200601.12

Received: December 7, 2019; Accepted: April 9, 2020; Published: April 30, 2020

\begin{abstract}
Mandarin (Citrus reticulata Blanco) is a premier fruit crop expanding rapidly in the hilly areas of Nepal. Most of the mandarin growers in Nepal are using conventional harvesting method which is responsible for deteriorating the fruit quality and shortening the postharvest shelf life. Thus, this experiment was conducted to evaluate the effect of different harvesting methods on quality and shelf-life of mandarin during storage under the Cellar condition $\left(11 \pm 2^{\circ} \mathrm{C}\right.$ and $\left.85-90 \% \mathrm{RH}\right)$. For this, mandarin fruits harvested by different methods i.e. hitting by sticks, direct pulling, twisting and pulling, and clipping were stored for 90 days and fortnight interval reading of different quality parameters were carried out. The experimental results revealed that fruits harvested by clipper with small pedicel intact recorded the minimum PLW (3.15\%), decay loss (8.33\%), and TSS $\left(10.57^{\circ}\right.$ Brix) and retained the higher fruit firmness $\left(3.30 \mathrm{~kg} / \mathrm{cm}^{2}\right)$, maximum juice recovery percentage (49.69), TA $(0.85 \%)$ and vitamin $\mathrm{C}(25.50 \mathrm{mg} / 100 \mathrm{ml})$ during the storage under Cellar condition. The study concluded that fruits harvesting with clipper can be stored safely up to three months under the Cellar condition.
\end{abstract}

Keywords: Fruit Firmness, Physiological Loss in Weight, Juice Content, Total Soluble Solids, and Titrable Acidity

\section{Introduction}

Mandarin (Citrus reticulata Blanco) is a leading fruit crop in Nepal due to its social and economic value. Mandarin shares 15.02 percent of total fruit production and distributing in 54 districts of the country [10]. Although the crop dominates to the total fruit industry in Nepal, however, quality of the fruit deteriorates with poor practices of harvesting and postharvest techniques. About 46 percent losses are reported from harvesting to distribution [2]. Farmers and traders face great losses immediately after harvesting and postharvest handling of fruits. Mandarin showed and estimated loss of $20-25 \%$ in transportation from field to market and up to $25 \%$ loss in cellar store stored for a period of 90 days [12].

Harvesting of the mandarin determines the marketability of the fruits. It is our bitter experience that people are generally used sticks to harvest mature fruits in the orchards which deteriorates the fruit quality and shelf life of the fruits and ultimately fetches poor price in the market. The methods of harvesting, injury to fruit during harvesting, and weather conditions during harvest greatly determine the extent of decay losses during subsequent handling and storage [7]. Harvesting by pulling can rupture the peel of loose skin oranges resulting in spoilage and harvesting by clipping keeping peduncle $2-3 \mathrm{~mm}$ is found effective to enhance the self-life [6]. Fruit with intact stalk were less prone to fungal infection during storage than those without fruit stalk [13]. In Nepalese context, most of the orchardists are using hands and stick to harvest the fruits which are prone to spoil and subsequent results poor quality. Conventional harvesting method is highly labour intensive and inefficient in terms of both economy and time [8]. Every year the loss caused by not adopting suitable methods of harvesting is increased after then reduced the market price. Therefore, this study was 
conducted to find out the effective harvesting methods on storage behaviour in cellar condition.

\section{Materials and Methods}

The studies on effect of harvesting methods on physiochemical parameters of the mandarin were carried out in 2013 and 2014 in Lamjung district. The physiological mature, uniform mandarin fruits with 50 percent yellow colour stage from the fifteen years old tree were harvested using different harvesting methods as a treatments $\left(T_{1}\right.$ : hitting by stick; $\mathrm{T}_{2}$ : direct pulling, $\mathrm{T}_{3}$ : twisting and pulling, and $\mathrm{T}_{4}$ : clipping by scissor) on November 15 . Immediately after harvesting, damaged fruits were culled and healthy fruits were selected for storage. The experiment was laid out in randomized complete block design and replicated in four times. Single tree was taken as an experimental unit. There were four trees with four replications. Ten fruits in each replication were taken for physiological loss in weight. Another 60 fruits were kept aside for quality analysis. The fruits were kept in cellar conditions at $11 \pm 2^{\circ} \mathrm{C}$ temperature and $85-90 \%$ relative humidity.

Various quality attributes were studied at 15 days interval for three months. Cumulative physiological loss in weight (PLW) was recorded by calculating the loss in weight of the fruit during storage over initial values. Decay loss was calculated on the basis of number of fruits spoiled. Total Soluble Solids (TSS) was determined by hand refractometer. Firmness was measured by penetrometer in $\mathrm{kg} / \mathrm{cm}^{2}$, juice was measured with measuring cylinder as expressed as percentage. Titrable Acidity (TA) was estimated by titrating diluted mandarin pulp juice with $0.1 \mathrm{~N}$ sodium hydroxide using phenolphthalein as an indicator and express as percentage of citric acid. Vitamin $\mathrm{C}$ was determined by titration with 2, 6-dichlorophenol-indolephenol dye solution as described by AOAC [1]. The data were tabulated and statistically analysed as mentioned by Gomez and Gomez $[5]$.

\section{Results and Discussion}

\subsection{Physiological Loss in Weight (PLW)}

Physiological loss in weight was increased significantly in all the treatments during storage and the range of weight loss percentage was found 1.05 in $15^{\text {th }}$ to 7.86 in $90^{\text {th }}$ day (Table 1). The loss in weight was minimum in the fruits harvested by clipper $(0.17 \%)$ and maximum in the fruits harvested by sticks $(2.05 \%)$ in first fortnight and similarly, the percentage weight loss was minimum in the fruits harvested with clipper $(3.15 \%)$ and maximum weight loss was observed in the fruits harvested by sticks $(15.81 \%)$ at the end of the storage. The higher loss in weight in the fruits harvested by sticks was due to the higher evapo-transpiration from the fruit surface and minimum weight loss in the clipped fruits was due to the less evapo-transpiration from the fruit surface during the storage. These findings were conformity with the findings of PHLRD [12] in mandarin as stated increased the weight loss with the increase in storage of mandarin fruits in Cellar condition. The loss in fruits weight was largely attributed to the water loss through evapo-transpiration through its stomata [14].

Table 1. Effect of harvesting methods on PLW and decay loss in mandarin fruit in Cellar condition.

\begin{tabular}{|c|c|c|c|c|c|c|c|c|c|c|c|c|}
\hline \multirow{3}{*}{ Methods of harvesting } & \multicolumn{12}{|c|}{ Days after storage } \\
\hline & \multicolumn{6}{|c|}{ PLW (\%) } & \multicolumn{6}{|c|}{ Decay loss (\%) } \\
\hline & 15 & 30 & 45 & 60 & 75 & 90 & 15 & 30 & 45 & 60 & 75 & 90 \\
\hline Hitting by stick & 2.05 & 5.67 & 8.41 & 10.89 & 12.70 & 15.81 & 35.00 & 58.33 & 63.75 & 69.16 & 74.33 & 80.00 \\
\hline Direct pulling & 1.58 & 2.41 & 3.73 & 4.84 & 6.75 & 8.82 & 13.33 & 36.50 & 50.00 & 58.33 & 65.00 & 66.66 \\
\hline Twisting and pulling & 0.41 & 0.67 & 1.04 & 1.55 & 2.59 & 3.65 & 0.00 & 1.67 & 3.33 & 5.83 & 11.66 & 18.33 \\
\hline Clipping by scissor & 0.17 & 0.34 & 1.00 & 1.33 & 1.90 & 3.15 & 0.00 & 0.83 & 1.67 & 2.50 & 5.00 & 8.33 \\
\hline Mean & 1.05 & 2.27 & 3.54 & 4.65 & 5.99 & 7.86 & 12.88 & 24.33 & 29.68 & 33.96 & 39.00 & 43.33 \\
\hline
\end{tabular}

\subsection{Decay Loss}

Data presented in the Table 1 shows that the decay loss of mandarin fruit storage under the Cellar condition was increased significantly with the advancement of the storage and it ranged $0-35 \%$ in first fortnight and reached 8.33 to $80 \%$ at the $90^{\text {th }}$ days of storage. The trends of decay loss was observed faster up to 45 days of storage period and immediately beyond that point the rate of decay loss was observed in gradual. The minimum decay loss was observed in the fruits harvested by clipper $(8.33 \%)$ followed by twisting and pulling (18.33\%) after 90 days of storage where as maximum decay loss $(80 \%)$ was recorded in the fruits harvested by hitting with stick. The clipped fruits were more intact and found less susceptible to microbes where as fruits harvested with direct with sticks were more susceptible to microbes and therefore, more susceptible to damage. Similar results were observed by PHLRD [11] that physical damage and mould infection, and loss in weight were greater in farmer's methods of harvesting than that of improved methods in mandarin. Similar result was drawn by Singh et al. [15] in mango fruits who observed decay loss, particularly stem end rot was less in the fruits harvested with stalk. Similarly, other workers [16] in Nagpur mandarin and [13] in mandarin drawn the same findings who reported that clipping fruit were less infected with green and blue mould during storage as compared to other methods of harvesting

\subsection{Fruit Firmness}

As depicted from the data in Table 2, the firmness of 
mandarin fruit was gradually declined from the first fortnight ( 4.12 to $\left.4.25 \mathrm{~kg} / \mathrm{cm}^{2}\right)$ to end of the storage (2.16 to 2.83 $\mathrm{kg} / \mathrm{cm}^{2}$ ) in all the treatments. Irrespective of harvesting methods, clipper had shown the significantly higher firmness $\left(3.30 \mathrm{~kg} / \mathrm{cm}^{2}\right)$ whereas minimum firmness was $\left(2.16 \mathrm{~kg} / \mathrm{cm}^{2}\right)$ observed in the fruits harvested by sticks at $90^{\text {th }}$ day after storage. The maximum firmness in the fruits harvested with clipper might be due to lesser mechanical injury to the fruit cells and minimum firmness in the fruits harvested by stick was might be due to the maximum mechanical injury i.e. bruising and rupturing on the fruit surface. This finding is in line with the report of Rana [14] who reported that firmness of fruits might be largely influenced by cell turgor and cell composition.

Table 2. Effect of harvesting methods on firmness and juice recovery in mandarin fruit in Cellar condition.

\begin{tabular}{|c|c|c|c|c|c|c|c|c|c|c|c|c|}
\hline \multirow{3}{*}{ Methods of harvesting } & \multicolumn{12}{|c|}{ Days after storage } \\
\hline & \multicolumn{6}{|c|}{ Firmness $\left(\mathrm{kg} / \mathrm{cm}^{2}\right)$} & \multicolumn{6}{|c|}{ Juice recovery (\%) } \\
\hline & 15 & 30 & 45 & 60 & 75 & 90 & 15 & 30 & 45 & 60 & 75 & 90 \\
\hline Hitting by stick & 4.12 & 3.83 & 3.52 & 3.10 & 2.75 & 2.16 & 53.06 & 48.72 & 43.94 & 37.53 & 32.56 & 26.62 \\
\hline Direct pulling & 4.15 & 3.85 & 3.60 & 3.30 & 2.95 & 2.38 & 52.98 & 50.69 & 48.30 & 46.52 & 44.83 & 42.74 \\
\hline Twisting and pulling & 4.25 & 3.95 & 3.77 & 3.45 & 3.23 & 2.83 & 53.80 & 52.09 & 50.83 & 49.09 & 47.84 & 47.00 \\
\hline Clipping by scissor & 4.25 & 4.10 & 3.95 & 3.75 & 3.58 & 3.30 & 53.38 & 53.08 & 52.56 & 51.99 & 50.85 & 49.69 \\
\hline Mean & 4.19 & 3.93 & 3.71 & 3.40 & 3.13 & 2.67 & 53.31 & 51.15 & 48.91 & 46.28 & 44.02 & 41.51 \\
\hline
\end{tabular}

\subsection{Juice Content}

The data presented in Table 2, revealed that the juice percentage pertaining the methods of harvesting was significantly $(\mathrm{p}=0.05)$ declined with the increased period of storage in all the treatments. The declining trends of juice was not significant in the first fortnight but immediately after the first fortnight the juice percentage was sharply declined to the end of the storage. The range of juice percentage was 53.06 to 53.80 in first fortnight and decreased as 26.62 to 49.69 at the end of the storage. The maximum juice percentage was recorded in the fruits harvested with clipper (49.69) followed by twisting and pulling (47.00) and minimum percentage of juice was found in the fruits harvested with stick (26.62) during the storage. The decreasing trends in juice percentage during the storage might be due to transpiration and respiration process under the Cellar condition. These findings corroborates with the findings of Bhusal [3] in the fruits of mandarin. The maximum juice percentage in the fruits harvested with clipper was might be due to less mechanical injury to the fruits and then less transpiration and respiration process.

\subsection{Total Soluble Solids (TSS)}

Table 3 shows that the TSS contents increased with the increase in storage period in all the treatments during the storage and ranged from $10.05^{\circ}$ Brix to $10.28^{\circ}$ Brix in the first fortnight and increased as $10.57^{\circ} \mathrm{Brix}$ to $11.89^{\circ} \mathrm{Brix}$ at the end of storage. The increasing trend of the TSS percentage in the fruits was not significant up to $15^{\text {th }}$ days then after it was increased significantly up to $90^{\text {th }}$ days of storage. The increase in TSS contents was faster in the fruits harvested by hitting with stick than those harvested by clipper. The higher TSS contents in the fruits harvested with stick $\left(11.89^{\circ} \mathrm{Brix}\right)$ and the lesser in the fruits harvested with clipper $\left(10.57^{\circ}\right.$ Brix $)$ might be due to higher metabolic activities resulted from opening and tearing of the fruit rind associated by hitting with stick. These results are in corroboration with the findings of Purbiati and Supriyanto [13] who reported that an increase in TSS may be attributed to the conversion of starch and other insoluble carbohydrates into soluble solids. The fruits harvested with sticks were more injured and had triggered high respiration process whereas in the fruits harvested with clippers and twisting and pulling were less injured with less respiration process.

Table 3. Effect of harvesting methods on TSS and TA in mandarin fruit under Cellar condition.

\begin{tabular}{|c|c|c|c|c|c|c|c|c|c|c|c|c|}
\hline \multirow{3}{*}{ Methods of harvesting } & \multicolumn{12}{|c|}{ Days after storage } \\
\hline & \multicolumn{6}{|c|}{ TSS $\left({ }^{\circ}\right.$ Brix $)$} & \multicolumn{6}{|c|}{ TA (\%) } \\
\hline & 15 & 30 & 45 & 60 & 75 & 90 & 15 & 30 & 45 & 60 & 75 & 90 \\
\hline Hitting by stick & 10.28 & 10.57 & 10.95 & 11.26 & 11.55 & 11.89 & 0.92 & 0.86 & 0.81 & 0.74 & 0.70 & 0.65 \\
\hline Direct pulling & 10.23 & 10.38 & 10.57 & 10.77 & 10.93 & 11.16 & 0.96 & 0.92 & 0.90 & 0.84 & 0.80 & 0.77 \\
\hline Twisting and pulling & 10.13 & 10.21 & 10.40 & 10.56 & 10.68 & 10.75 & 0.98 & 0.96 & 0.94 & 0.91 & 0.87 & 0.84 \\
\hline Clipping by scissor & 10.05 & 10.20 & 10.27 & 10.38 & 10.46 & 10.57 & 0.99 & 0.98 & 0.95 & 0.93 & 0.89 & 0.85 \\
\hline Mean & 10.17 & 10.34 & 10.55 & 10.74 & 10.90 & 11.09 & 0.96 & 0.93 & 0.90 & 0.86 & 0.82 & 0.78 \\
\hline
\end{tabular}

\subsection{Titrable Acidity (TA)}

Perusal from the data shown in Table 3, the percentage of TA declined with time in the storage in all treatments and ranged from $0.92-0.99$ on $15^{\text {th }}$ day to $0.65-0.85$ on $90^{\text {th }}$ day. The decline in acidity percentage was much higher in the fruits harvested with stick (0.65), however, maximum percentage of acidity was found in the fruits harvested with 
clipper (0.85) which was statistically at par with twisting and pulling (0.84). The sharp decline of TA percentage in the fruits harvested with stick during the storage might be higher losses during the transpiration and respiration process. These results are in corroboration with the findings of Deka et al. [4] in Khasi mandarin, and [13] in mandarin who reported declining trend of mandarin progressed during the storage. [16] reported that the total soluble solids content did not change much while TA dropped more so in snap harvested fruit as compared to clipped fruit.

\subsection{TSS/Acid Ratio}

$\mathrm{TSS} / \mathrm{TA}$ ratio is strong parameter to determine the ripening stage of the fruit. Table 4 shows that TSS/acid ratio increased significantly with the advancement of storage in all the treatments and ranged from $10.27-11.25$ at $15^{\text {th }}$ day to 12.61 19.00 at $90^{\text {th }}$ day of storage. The maximum TSS/acid ratio was recorded in the fruits harvested by sticks (19.00) and minimum ratio was observed in the fruits harvested by clippers (12.61) at the end of the storage. The increase in TSS/acid ratio might be increasing in TSS and decreasing in acid in the fruits with the advancement of the storage period. These results are in consonance with the findings of Sonkar et al. [16] in Nagpur mandarin and [4] in Khasi mandarin and [12] in mandarin.

\subsection{Vitamin C Content}

Vitamin $\mathrm{C}$ content decreased with the increase in storage period in all the treatments. As shown in Table 4, Vitamin C content decreased as $42.29-40.04 \mathrm{mg} / 100 \mathrm{ml}$ to $22.57-25.50$ $\mathrm{mg} / 100 \mathrm{ml}$ from $15^{\text {th }}$ day to $90^{\text {th }}$ day of storage under Cellar condition. The vitamin $\mathrm{C}$ content recorded highest in the fruits harvested by clippers $(25.50 \mathrm{mg} / 100 \mathrm{ml})$ and the lowest was found in the fruits harvested by sticks $(22.57 \mathrm{mg} / 100 \mathrm{ml})$ at the end of the storage. The loss in vitamin $\mathrm{C}$ content is associated with enzymatic degradation which is caused by rupturing the cells in the fruits. This finding is in line with the report of Mapson [9] reported that a significant decrease in ascorbic acid at later ripening stage and injured fruits which could be due to enzymatic loss of L-ascorbic acid to 23- dioxy-L-gluconic acid.

Table 4. Effect of harvesting methods on TSS/acid ratio and vitamin C in mandarin fruit under Cellar condition.

\begin{tabular}{|c|c|c|c|c|c|c|c|c|c|c|c|c|}
\hline \multirow{3}{*}{ Methods of harvesting } & \multicolumn{12}{|c|}{ Days after storage } \\
\hline & \multicolumn{6}{|c|}{ TSS/acid ratio } & \multicolumn{6}{|c|}{ Vitamin C (mg/100 ml) } \\
\hline & 15 & 30 & 45 & 60 & 75 & 90 & 15 & 30 & 45 & 60 & 75 & 90 \\
\hline Hitting by stick & 11.25 & 12.33 & 13.64 & 15.31 & 16.73 & 19.00 & 40.76 & 37.34 & 32.70 & 29.05 & 25.91 & 22.57 \\
\hline Direct pulling & 10.79 & 11.39 & 12.02 & 13.00 & 13.92 & 14.85 & 40.04 & 37.12 & 32.44 & 29.38 & 26.37 & 23.15 \\
\hline Twisting and pulling & 10.50 & 10.77 & 11.24 & 11.67 & 12.35 & 13.01 & 42.29 & 39.48 & 34.72 & 30.77 & 27.46 & 24.13 \\
\hline Clipping by scissor & 10.27 & 10.59 & 11.00 & 11.27 & 11.89 & 12.61 & 41.29 & 37.71 & 34.73 & 31.26 & 27.97 & 25.50 \\
\hline Mean & 10.70 & 11.27 & 11.98 & 12.81 & 13.72 & 14.87 & 41.09 & 37.91 & 33.65 & 30.12 & 26.93 & 23.84 \\
\hline
\end{tabular}

\section{Conclusions}

Fruit harvested by clippers were superior in quality and shelf life with minimum PLW (3.15\%) and decay loss $(8.33 \%)$; and also had retained the higher fruit firmness $(3.30$ $\left.\mathrm{kg} / \mathrm{cm}^{2}\right)$, maximum juice content $(49.69 \%)$, and vitamin $\mathrm{C}$ $(25.50 \mathrm{mg} / 100 \mathrm{ml})$ during storage under Cellar condition as compared to control. This indicates the greater implication of clippers during harvesting of mandarin fruit.

\section{Acknowledgements}

Fellowship provided by University Grants Commission (UGC) is duly acknowledged.

\section{References}

[1] AOAC. (2005). Official methods of analysis (16 ${ }^{\text {th }}$ edition). Association of official analytical chemists. Washington D. C. USA.

[2] Bhattarai, R. M., Rijal, R. K., and Mishra, P. (2013). Postharvest losses in mandarin orange: A case study of Dhankuta district of Nepal. African Journal of Agricultural
Research, 8 (9): 763-767.

[3] Bhusal, Y. (2002). Improvement of postharvest shelf life of mandarin orange (Citrus reticulata Blanco), M. Sc. Thesis. IAAS. Rampur, Chitwan.

[4] Deka, B. C., Sharma, S., and Borah, S. C. (2006). Postharvest management practices for shelf life extension of Khasi mandarin. Indian Journal of Horticulture, 63 (3): 251-255.

[5] Gomez, A. K., and Gomez, A. A. (1984). Statistical procedures for Agricultural Research. John Wiley and Sons Inc., New York.

[6] Ladaniya, M. S. (2001). Postharvest technology of fresh citrus fruits. In: eds. S. Singh and S. A. M. H. Naqvi, Citrus. International book distributing company, Lukhnow, India, pp. 459-473.

[7] Ladaniya, M. S. (2008). Citrus fruit: biology, technology and evaluation. Elsevier inc. USA. pp. 1-10.

[8] Li, P., Lee, S., and Hsu, H. Y. (2011). Review in fruit harvesting method for potential use of automatic fruit harvesting systems. Elsevier, Procedia Engineering, 23: 351366. www.sciencedirect.com.

[9] Mapson, L. W. (1970). The biochemistry of fruits and their products. (Ed. Hulme, A. C.) Academic press. London. 1: 369384. 
[10] MOAD (2016). Statistical information on Nepalese agriculture. Ministry of Agricultural Development. Kathmandu, Nepal, p. 219.

[11] PHLRD (2003). Study on loss assessment of mandarin orange in different postharvest operations from harvest to storage. Postharvest loss reduction division, Kathmandu, Nepal. pp 7 15.

[12] PHLRD, (2005). Food loss status in Nepal. Progress report. Postharvest loss reduction division. Post harvest management directorate, Kathmandu. Nepal. pp. 3-3.

[13] Purbiati, T. and Supriyanto, A. (2013). Effect of harvesting methods and storage temperature on shelf life of mandarin fruit cultivar 'SoE' from East Nusa Tenggara, Indonesia. Acta
Horticulture, International Society for Horticultural Science (ISHS), 989: 149-152. Retrieved from: http://www.actahort.org/books/989/989_18.htm.

[14] Rana, M. K. (2006). Ripening changes in fruits and vegetables-A review. Haryana Journal of Horticulture science, 35 (3-4): 271-279.

[15] Singh, B. P., Parla, S. K., and Tonden, D. K. (1993). Effect of methods of harvesting on storage behaviour of mango. Indian Journal of Horticulture, 50 (1): 5-9.

[16] Sonkar, P. K., Ladaniya, M. S., and Singh, S. (1999). Effect of harvesting methods and post-harvest treatments on storage behaviour of Nagpur mandarin (Citrus reticulata) fruit. The Indian Journal of Agricultural Science, 69 (6): 1-6. 